Article

\title{
Large-Scale Grain Producers' Application of Land Conservation Technologies in China: Correlation Effects and Determinants
}

\author{
Xiaojuan Luo ${ }^{1}$, Shuyi Feng ${ }^{2, *}$, Hongbin Liu ${ }^{3}$ and Bo Zhao ${ }^{1}$ \\ 1 Jiangxi Economic Development Research Institute, Jiangxi Normal University, Nanchang 330027, China; \\ 1xj918@126.com (X.L.); zhaobo507@yeah.net (B.Z.) \\ 2 College of Public Administration, Nanjing Agricultural University, Nanjing 210095, China \\ 3 College of Land and Environment, Shenyang Agricultural University, Shenyang 110866, China; \\ liuhongbinsy@syau.edu.cn \\ * Correspondence: shuyifeng@njau.edu.cn; Tel.: +86-136-051-56775
}

Received: 30 November 2018; Accepted: 10 January 2019; Published: 16 January 2019

\begin{abstract}
The quality of cultivated land has been seriously degraded due to the overuse of chemical fertilizer in China. Land conservation technologies (LCTs) have been proven to effectively address land degradation and improve land productivity. In this study, a multivariate probit model is applied to empirically analyze the correlation effects and determinants of the application of LCTs application using cross-sectional data collected on 690 large-scale grain producers from the Jiangsu and Jiangxi provinces in the middle and lower reaches of the Yangtze River. The sample farmers were individually investigated by face-to-face questionnaires in the field that included around 400 questions. The results revealed that there are significant complementary relationships among farm manure application, commercial organic fertilizer use, and green manure plantation, and between formula fertilization and straw returning. Regarding the determinants, highly educated farmers and farmers with a large farm size and high incomes are more likely to adopt LCTs. The land size variable shows an inverted U-shaped relationship with formula fertilization, with an inflection point at $153 \mathrm{mu}$ (10.20 ha), while showing an U-shaped relationship with commodity organic fertilizer use and green manure plantation technologies, with the turning points at $207 \mathrm{mu}(13.80 \mathrm{ha})$ and $124 \mathrm{mu}(8.27 \mathrm{ha})$, respectively. The results also indicate that extension services from agricultural technicians, agricultural technical information, and policy knowledge variables have positive effects on the application of LCTs, while the subsidy policy variable does not appear to have the expected effect. To promote the application of LCTs, suggestions include improving the extension system, selecting targeted farmers for extension training, expanding environmental policy advocacy to increase farmers' knowledge about land degradation, and adjusting subsidies.
\end{abstract}

Keywords: land conservation technologies; correlation effect; multivariate probit model; large-scale grain producers

\section{Introduction}

Land degradation caused by the excessive use of chemical fertilizer has been particularly serious in China due to aggressive urbanization and intensive agriculture development over the last few decades. According to the National Bureau of Statistics of China, the average amount of chemical fertilizer application was $359.08 \mathrm{~kg} / \mathrm{ha}$ in crop production in 2016 [1], which was nearly 1.60 times the international safety threshold (225 kg/ha) [2]. However, the absorptivity of nitrogenous fertilizer, phosphate fertilizer, and potash fertilizer were just $30 \%, 10 \sim 25 \%$, and $35 \sim 50 \%$, respectively, which were much lower than the nutrient absorption rates of up to $60 \sim 70 \%$ in developed countries [3,4]. The excessive application but 
low absorptivity of chemical fertilizer has not only led to to land degradation such as soil acidification [5] and soil fertility reduction [6], but also the eutrophication of rivers and lakes [7,8], and even greenhouse gas emissions [9].

In order to reduce chemical fertilizer use intensity and protect cultivated land, a series of protection policies and measures are promulgated in China [10-12]. "The action plan for protecting and promoting the quality of cultivated land" and "The action plan of zero growth in fertilizer application until 2020", which were issued by the Ministry of Agriculture and Rural Affairs, point out that land conservation measures and technologies in terms of applying farm manure, straw returning, formula fertilization, and green manure plantation can effectively increase the organic matter content in soil and land productivity.

Although the above measures and techniques have achieved remarkable effects in experiment and pilot areas, the progress of extension at the large scale is very slow. As a result, questions arise regarding the difficulties during the process of extending LCTs, and which factors mainly determine the application of LCTs. The answers to these two questions are of great interest to policymakers.

As the end adopters, farmers play an important role in land conservation [13-15]. Most of the previous studies have treated farmers' application of LCTs as mutually independent behavior, while less literature has paid attention to the interaction among various LCTs application. Related to empirical studies, the binary choice model is usually approached in examining the determinant of LCTs application [16-18]. The extent of application is often investigated using truncated Tobit models or Cragg's double-hurdle model [19-21], while the frequency of application is analyzed by an ordered probit model or multinomial logit model [22,23]. Generally, available research studies make individual estimations and ignore the interactions among different applications of LCTs. However, in real production, farmers often choose multiple LCTs at the same time, and there may be close relationships among different applications of LCTs. Therefore, if unobserved variables affect the application of different technologies simultaneously, the individual estimation of each technology applying the traditional binary model may produce biased estimates. The multivariate probit model might be a good method to address these problems.

Moreover, previous studies have mainly paid attention to the application behavior of small-scale farmers regarding LCTs. In order to enhance agricultural modernization, the central government has advocated agricultural-scale management in recent years in China. Meanwhile, many preferential policies of agriculture are inclined to large-scale agricultural operators in terms of large and specialized agricultural businesses, family farms, farmer cooperatives, and agribusinesses. According to the statistics of the Ministry of Agriculture and Rural Affairs, the number of large-scale agricultural operators exceeded 3.5 million, and their operated cultivated land area exceeded 0.2 billion ha, accounting for close to $1 / 3$ of the total contracted cultivated land area in 2016 [24].

Therefore, the objective of this paper is to empirically examine the correlation effects and determinants of large-scale grain producers' (note: According to the official identification in southern China, large-scale grain producers are those whose total sown area of grain is equal or more than 3.33 ha.) application of various LCTs using cross-sectional data collected on 690 large-scale grain producers from Jiangsu and Jiangxi provinces in the middle and lower reaches of the Yangtze River. Specially, we aim to answer the following two questions: whether there are complementary or substitute relationships among individual LCTs' application; and whether are there any differences in the application determinants of various LCTs. A better understanding of the barriers to the application of LCTs may help policymakers and extension staff more effectively promote LCTs.

\section{Data and Description of Technologies Application}

\subsection{Data Collection}

The paddy of the middle and lower reaches of the Yangtze River is one of the most important grain-producing areas in China. However, excessive fertilizer application results in many problems 
in terms of soil acidification, land fertility reduction, and heavy metal pollution $[5,6,25,26]$. This is the main reason to select this area as study region, and specially choose Jiangxi Province and Jiangsu Province as survey areas (see Figure 1). On one hand, the two sample provinces are both in the ecologically sensitive basin areas. Jiangxi Province is perched on Poyang Lake, which is not only the biggest freshwater lake in China, but also the biggest ecological wetland in Asia, while Jiangsu Province is located in Taihu Lake Basin, which is the second largest freshwater lake in China. On the other hand, the two sample provinces respectively represent the developing regions and the developed regions in China. Differences among the large-scale producers' application of LCTs under different economic development levels can also be explored.

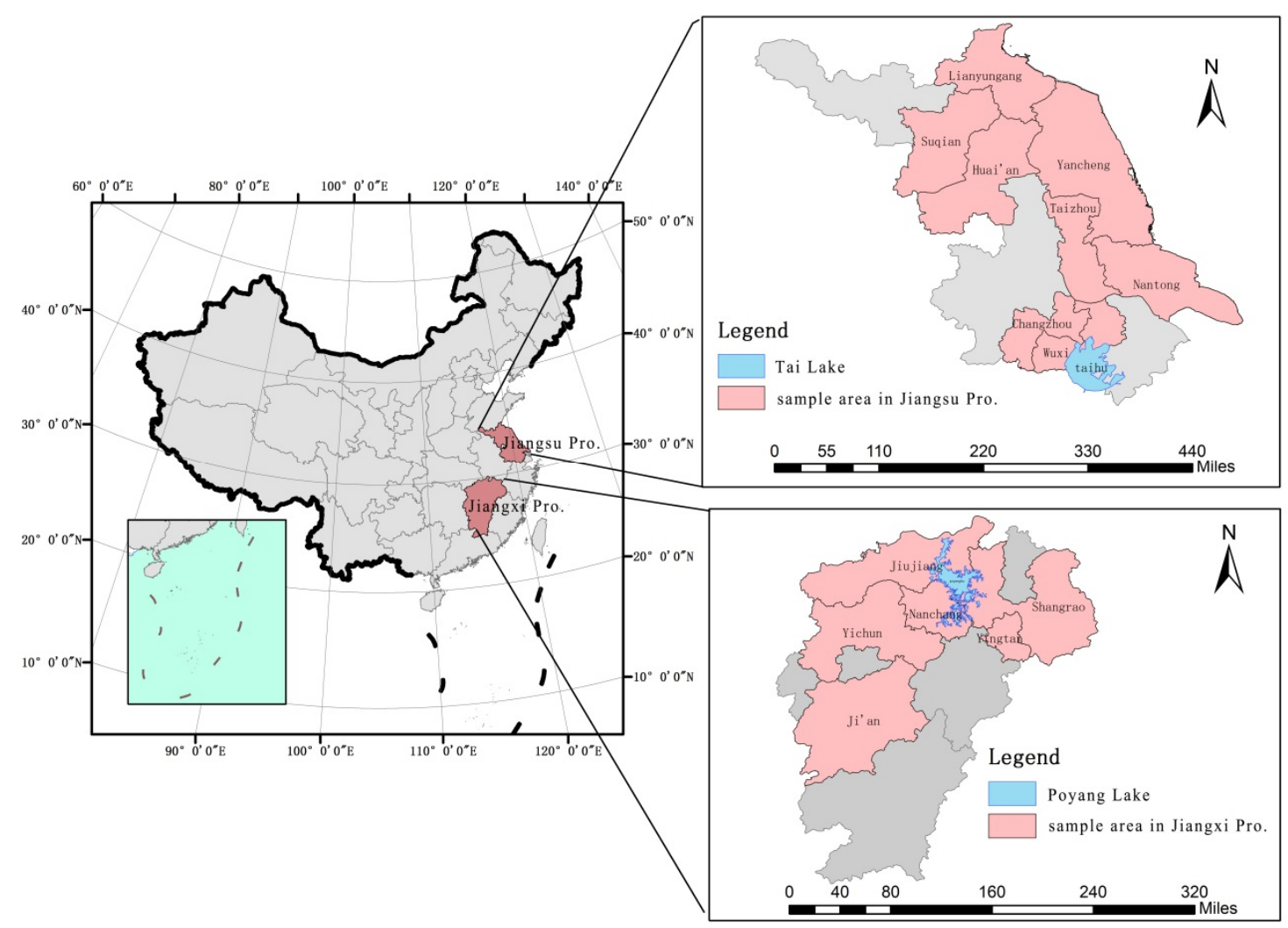

Figure 1. Location of the study areas in Jiangsu and Jiangxi provinces, China.

The data used in this study were collected from a sampling survey of 690 large-scale grain producers in survey areas from July to September 2016. The stratified random sampling was adopted in samples selection. First of all, eight sample counties (districts) were selected according to the economic situation and cultivated land area in each province. From each selected county, two to four sample towns were randomly selected based on the proportion of cultivated land area. We then randomly selected 20 famers according to the roster of large-scale grain producers in each town. As a result, a total of 704 large-scale grain producers in 40 towns from two provinces were individually investigated through a face-to-face questionnaire survey by trained interviewers consisting of $\mathrm{PhD}$, Masters, and undergraduate students majoring in agricultural and resource economy. We finally used 690 samples after eliminating samples with insufficient information and without grain planting. A structured questionnaire with three sections was used in this survey that included about 400 questions, nearly half of which were open questions. The first section collected information regarding the characteristics of the individual large-scale grain producer and his/her household, such as the age, education level, cultivated areas, off-farm employment, among others. The second part related to the application of LCTs. The third section involved gain production, including inputs (i.e., labor input, fertilizer intensity, pesticide used) and outputs. 


\subsection{Technologies Application}

The LCTs in this study mainly include farm manure application, commercial organic fertilizer use, formula fertilization, green manure plantation, and straw-returning technology (see Table 1). Specifically, farm manure application mainly refers to using the manure of human and livestock as fertilizer. Farm manure contains large amount of organic matter that is difficult to decompose, resulting in the nutrients being difficult to be absorbed or utilized by the crops directly. It's said that farm manure needs at least three to five years to be fermented and decomposed [27]. Farm manure application is a labor-intensive traditional technology because of the large amount of application and the high cost of collection and transportation.

Table 1. Characteristics of the five land conservation technologies (LCTs).

\begin{tabular}{cccccc}
\hline & Farm Manure & $\begin{array}{c}\text { Commercial } \\
\text { Organic Fertilizer }\end{array}$ & $\begin{array}{c}\text { Formula } \\
\text { Fertilization }\end{array}$ & $\begin{array}{c}\text { Green Manure } \\
\text { Plantation }\end{array}$ & $\begin{array}{c}\text { Straw } \\
\text { Returning }\end{array}$ \\
\hline $\begin{array}{c}\text { Environment-friendly } \\
\text { technology }\end{array}$ & $\sqrt{ }$ & $\sqrt{ }$ & $\sqrt{ }$ & $\sqrt{ }$ \\
$\begin{array}{c}\text { New technology } \\
\text { Traditional technology } \\
\text { Short-term investment } \\
\text { Long-term investment }\end{array}$ & $\sqrt{ }$ & $\sqrt{ }$ & $\sqrt{ }$ & $\sqrt{ }$ & $\sqrt{ }$ \\
\hline
\end{tabular}

Commercial organic fertilizer actually consists of farm manure processed by fertilizer manufacturers, and its organic matter is fully decomposed into humus, which is easier to be absorbed [28]. Moreover, the nutrient ratio of commercial organic fertilizer can be adjusted according to different soil conditions, so the nutrient proportion is more reasonable than original farm manure [28]. Obviously, the price of commercial organic fertilizer is much higher than farm manure. Overall, it is a labor and capital-intensive technology, as well as a new technology.

Formula fertilization is a new technology that refers to arranging the application quantity and proportion of nitrogen, phosphorus, potassium, and other medium elements according to the crops' growth stage and nutrient demands $[29,30]$. Compared to organic fertilizer, the technically-based formula fertilization is much more effective on major nutrient supply to crops, but does not provide any ground for organic matter conservation and increase in soils. Formula fertilization can reduce fertilizer application and increase the yield, but it needs more labor input due to site-specific management [30].

Green manure belongs to biological fertilizer with complete nutrients. The stems and leaves of green manure crops are rich in nutrients, which can greatly increase the organic matter, nitrogen, phosphorus, potassium, and various trace elements in the soil after it is decomposed [31,32]. Green manure crops not only have great effects on the improvement of soil fertility, but also prevent or reduce the loss of water, soil, and fertility due to lush stems and leaves covering the ground. Compared to the other LCTs, green manure needs only a small amount of seeds and fertilizer, which has lower labor and transportation costs. Therefore, green manure plantation is a traditional technology that is not high in the demand of labor or capital.

Straw returning technology is a new technology that refers to applying the straw to the field as fertilizer by chemical decaying or mechanical pulverization, which can not only increase the content of organic matter in soil, but also avoid the air pollution caused by straw burning. Previous studies have indicated that straw returning significantly improved soil structure and increased soil nutrients content in terms of soil organic matter, total nitrogen, available phosphorus, and potassium after continuous application for several years $[33,34]$. In our study area, straw returning is generally comminuted by machine, which is a new capital-intensive technology due to renting the machine.

Figure 2 shows the number of adopters of each LCT in the sample areas. In view of the overall technology application, the application rate of straw returning technology is the highest, reaching $72.75 \%$, while the application rates of farm manure application, commercial organic fertilizer use, and green manure plantation are less than $15 \%$. Specially, the application rate of the formula 
fertilization is only $21.45 \%$, which has been the key popularized project tactic by the government since 2005. In view of the regional differences in technology application, the application rate of farm manure application, commercial organic fertilizer use, and straw returning technology in Jiangsu Province were higher than that in Jiangxi Province. Meanwhile, the adoption of formula fertilization and straw returning technology were the opposite.

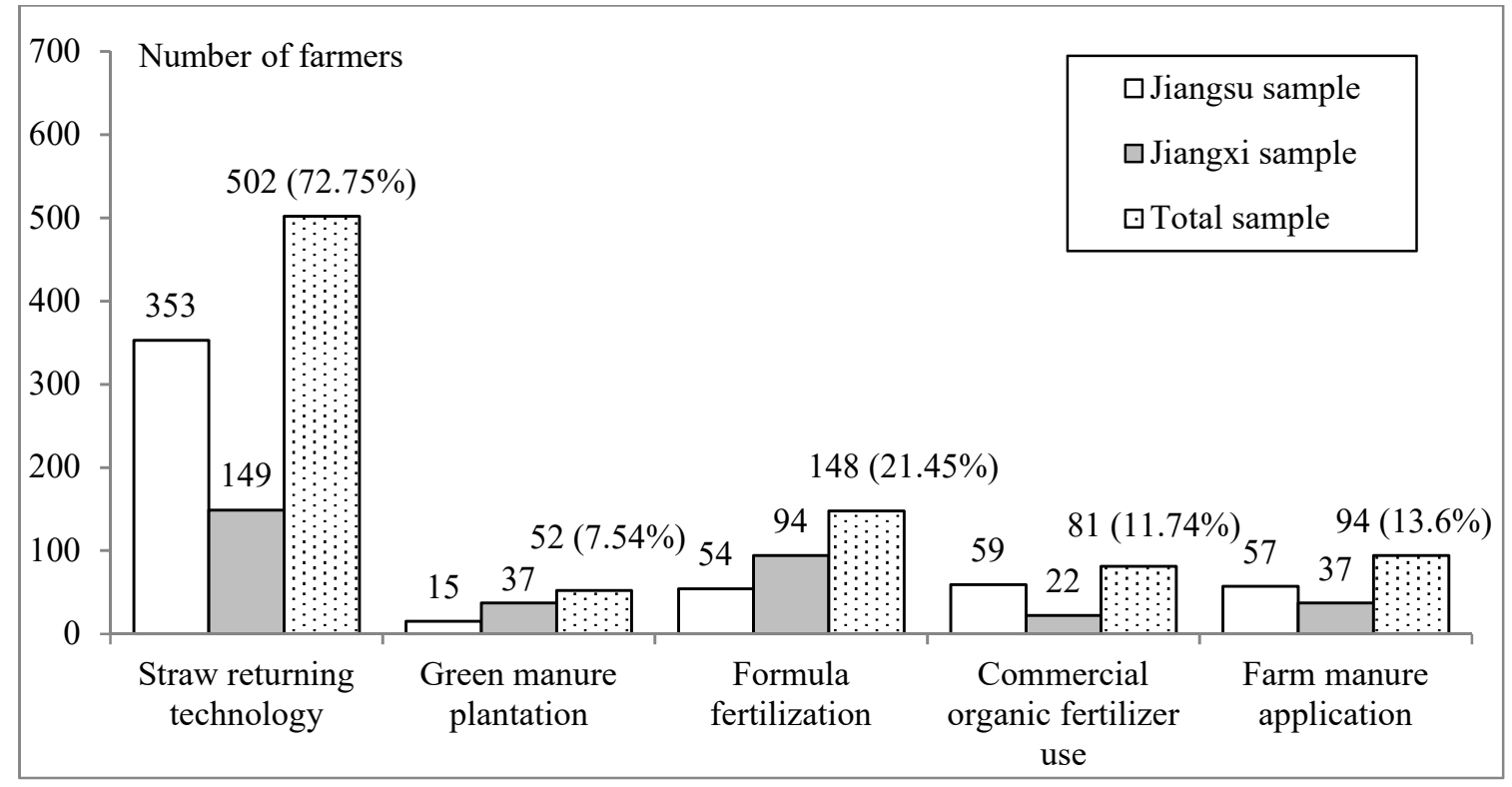

Figure 2. Numbers and proportion of adopters of land conservation technologies (LCTs) in sample areas. Note: The percentage in the parenthesis above the third bar per category means the proportion of the corresponding LCT adopters in the total sample.

\section{Methodology}

\subsection{Empirical Model}

Large-scale grain producers may simultaneously select multiple LCTs. If we individually estimate each technology application applying traditional binary model and ignoring the correlation between the error terms of different models, we might get biased estimates. To avoid this problem, a multivariate probit model is a good choice, which allows the existence of correlation among the error terms of different equations [35]. For cross-sectional data, the multivariate probit model can be expressed as follows:

$$
\begin{gathered}
Y_{j}^{*}=\beta_{j} X+\mu_{j} \\
Y_{j}=\left\{\begin{array}{r}
1, \text { If } Y_{j}^{*}>0 \\
0, \text { others }
\end{array}\right.
\end{gathered}
$$

where $Y_{j}^{*}$ is an unobserved latent variable consisting of multiple binary dependent variables; meanwhile, $j=1,2,3,4$, and 5 , respectively indicate the application of farm manure, commercial organic fertilizer, formula fertilization, green manure plantation, and straw returning technology. Meanwhile, $Y_{j}$ is the final result variable; if $Y_{j}^{*}>0, Y_{j}$ is 1 , indicating that large-scale grain producers adopt the corresponding technology, otherwise, it is $0 . X$ is a vector of variables that may affect technology application, including the farmer and household characteristics, land endowment, technology information, and policy cognition; $\beta$ is a vector of unknown parameters to be estimated; $\mu \sim N(0, \sigma 2)$ refers to those factors that are not included in the model, such as measurement errors and left-out explanatory variables. 
The covariance $\psi$ conforms to the multivariate normal distribution covariance. The covariance matrix is as follows:

$$
\psi=\left[\begin{array}{ccccc}
1 & \rho_{12} & \rho_{13} & \rho_{14} & \rho_{15} \\
\rho_{21} & 1 & \rho_{23} & \rho_{24} & \rho_{25} \\
\rho_{31} & \rho_{32} & 1 & \rho_{34} & \rho_{35} \\
\rho_{41} & \rho_{42} & \rho_{43} & 1 & \rho_{45} \\
\rho_{51} & \rho_{52} & \rho_{53} & \rho_{54} & 1
\end{array}\right]
$$

where the non-diagonal elements represent the unobservable links among the random perturbation terms of the five models. The non-zero value of the non-diagonal elements means that there is a correlation between the two random perturbations of the corresponding equations, which indicates that it is suitable to apply the multivariate probit model. The positive value of the element shows that there is a complementary effect between the applications of the two technologies, while the negative value implies the substitute effect.

\subsection{Variable Definition and Descriptive Statistics}

Previous studies on the determinants of environment-friendly agricultural technologies have grouped factors affecting technology application into five categories, namely: farmer characteristics (Age, Education, Cadre, and Risk), farm household characteristics (Hsize, Hincome, and Off-Farm), land endowment (Lscale, Fragmentation, Road, and Lsecurity), technology information and policy variables (Extension, Tinformation, Policy, and Subsidy). Table 2 summarizes the definitions, descriptive statistics and expected effects of the variables.

It's worth noting that the risk attitude of farmers was investigated by asking the following seven measure events based on a five-point Likert scale, in which one was labeled strongly disagree, three indicated neither agree nor disagree, and five meant strongly agree. (1) No risk, no income; (2) I am willing to take more risk to gain more income; (3) I would like to invest something without risk; (4) I do not invest in some new products because of the risk; (5) I would prefer a riskless investment; (6) I would invest heavily in some profitable investment and even take out a loan from others for this investment; (7) I like to attend the lottery due to the chance of gaining lots of money unexpectedly. Secondly, we unified the risk attitude direction of each question due to a higher score meaning risk preference in some events and risk aversion in other events. Then, we calculated the risk index based on the average score of the seven measure events. Regarding the farmer and household characteristics variables, most of the surveyed large-scale grain producers are at the age of 40 50 years, and have a middle school education, which is consistent with most of the farmers in China being middle-age with limited education [36] (see Table 2). Three percent of the survey respondents undertook a post of village cadres. Most of the samples tended to be risk-averse. The average number of family members of the surveyed grain producers was nearly five, and their average household annual gross income was RMB 450,000 (USD 65,880), with an off-farm income share at about $23 \%$. This is quite different from the ordinary small-scale farmers in rural China, whose off-farm income proportion is around $40 \%[37,38]$. Regarding land management characteristics variables, due to the respondents being large-scale grain producers, the mean cultivated land is $264.06 \mathrm{mu}$ (17.6 ha), but only $13 \%$ of the respondents obtained a certificate for management rights on rented land. However, each household had on average 90 plots, resulting in the serious fragmentation of land holdings ( 0.19 ha per plot). Related to technical information and policy variables, $77 \%$ of the samples received agricultural technology information from various media, which included an agricultural technology extension station, TV, and network, among others. Most of the respondents know a little about the zero growth policy of chemical fertilizer, and approximately $76 \%$ of the samples get related subsidies to large-scale grain producers. 
Table 2. Definition and descriptive statistics of the variables.

\begin{tabular}{|c|c|c|c|}
\hline Variables & Definition & Mean & S.D. \\
\hline \multicolumn{4}{|c|}{ Dependent variables } \\
\hline T1 & 1 = Farmer applied farm manure; $0=$ otherwise & 0.14 & 0.34 \\
\hline T2 & $1=$ Farmer applied commercial organic fertilizer; $0=$ otherwise & 0.12 & 0.32 \\
\hline T3 & $1=$ Farmer applied formula fertilization; $0=$ otherwise & 0.21 & 0.41 \\
\hline $\mathrm{T} 4$ & $1=$ Farmer planted green manure; $0=$ otherwise & 0.08 & 0.26 \\
\hline T5 & $1=$ Farmer applied straw returning technology; $0=$ otherwise & 0.73 & 0.44 \\
\hline \multicolumn{4}{|c|}{ Independent variable } \\
\hline Age & $\begin{array}{l}\text { Age of household head, } 1=\text { less than } 30 \text { years; } 2=31-40 \text { years; } \\
3=41-50 \text { years; } 4=51-60 \text { years; } 5=\text { older than } 60 \text { years }\end{array}$ & 3.58 & 0.86 \\
\hline Education & $\begin{array}{l}\text { Education of household head, } 1=\text { primary school or below; } \\
2 \text { = middle school; } 3 \text { = high school; } 4=\text { college or above }\end{array}$ & 2.02 & 0.83 \\
\hline Cadre & $1=$ household head is a village cadre; $0=$ otherwise & 0.03 & 0.16 \\
\hline Risk & $\begin{array}{l}\text { Risk attitude of household head, } 1=\text { risk averse; } \\
5=\text { risk preference. Risk preference is rising from } 1 \text { to } 5\end{array}$ & 2.89 & 0.56 \\
\hline Hsize & Family members in total & 4.86 & 1.91 \\
\hline Hicome & Household annual income, 10 thousand Yuan & 45.00 & 78.11 \\
\hline Off-farm & Share of off-farm income to total income, $\%$ & 0.23 & 0.23 \\
\hline Lscale $^{a}$ & Land scale, Mu (ha) & $264.06(17.60)$ & $474.62(31.64)$ \\
\hline Fragmentation & Number of land plots & 90.44 & 190.03 \\
\hline Road & $\begin{array}{l}\text { Road construction in field: } 1=\text { very bad; } 2=\text { bad } ; 3=\text { medium; } \\
4=\text { good } 5=\text { very good }\end{array}$ & 3.38 & 1.03 \\
\hline Rotation & $1=$ single cropping; $0=$ double cropping & 0.23 & 0.42 \\
\hline Lsecurity & $1=$ obtained certificate $0=$ otherwise & 0.13 & 0.33 \\
\hline Extension & Assess to extension service: $1=$ no; $2=$ medium $3=$ yes & 2.35 & 0.86 \\
\hline Tinformation & $\begin{array}{l}\text { Obtained agricultural technology information from various } \\
\text { media: } 1=\text { yes; } 0=\text { no }\end{array}$ & 0.77 & 0.42 \\
\hline Policy & $\begin{array}{l}\text { Knowledge on zero growth of chemical fertilizer policy: } \\
1=\text { never heard of; } 2=\text { a little; } 3=\text { basically understand; } \\
4=\text { understand well; } 5=\text { full knowledge }\end{array}$ & 2.30 & 1.18 \\
\hline Subsidy & $\begin{array}{l}1=\text { get related subsidies to large-scale grain producers; } \\
0=\text { otherwise }\end{array}$ & 0.76 & 0.43 \\
\hline Region & Region dummy: $1=$ Jiangsu; 0 = Jiangxi & 0.52 & 0.50 \\
\hline
\end{tabular}

Note: In the empirical model, the square term of the land management scale is introduced to capture the possible nonlinear relationship between land area and the application of LCTs.

\section{Results}

\subsection{Correlation Effects}

Stata14.0 is used to estimate the multivariate probit model for the application behavior of large-scale grain producers for the various technologies, and Table 3 shows the covariance matrix of the regression equation. The results show that the chi-square value of the model is 49.14 with $p=0.000$, indicating that correlation indeed exists among the random perturbation terms of various equations, and it is appropriate to use the multivariate probit model in this study. There are four covariances in the matrix that passed the significance test, and all of them had a positive correlation, which shows that there are significant complementary relationships among the application of farm manure, commercial organic fertilizer use, and green manure plantation, and between formula fertilization and straw returning technology. 
Table 3. Covariance matrix of regression for the multivariate probit model.

\begin{tabular}{cccccc}
\hline & Farm Manure & $\begin{array}{c}\text { Commercial } \\
\text { Organic Fertilizer }\end{array}$ & $\begin{array}{c}\text { Formula } \\
\text { Fertilization }\end{array}$ & $\begin{array}{c}\text { Green Manure } \\
\text { Plantation }\end{array}$ & $\begin{array}{c}\text { Straw } \\
\text { Returning }\end{array}$ \\
\hline Farm manure & - & - & - & - & - \\
Commercial organic fertilizer & $0.237^{* * *}(0.083)$ & - & - & - & - \\
Formula fertilization & $-0.057(0.078)$ & $0.027(0.084)$ & - & - & - \\
Green manure plantation & $0.451^{* * *}(0.082)$ & $0.364^{* * *}(0.094)$ & $-0.111(0.096)$ & - & - \\
Straw returning technology & $0.037(0.090)$ & $0.013(0.094)$ & $0.269^{* * *}(0.080)$ & $0.083(0.105)$ & - \\
\hline
\end{tabular}

Note: The null hypothesis of the likelihood ratio test: $\rho_{21}=\rho_{31}=\rho_{41}=\rho_{51}=\rho_{32}=\rho_{42}=\rho_{52}=\rho_{43}=\rho_{53}=\rho_{54}=0$, chi-square $=49.14$, and $p$-value $=0.000$. The parenthesis is standard error. ${ }^{*}, * *, * *$ denote statistical significance at $10 \%, 5 \%$, and $1 \%$.

\subsection{Estimation Results}

Table 4 and Figure 3 show the estimation results of multivariate probit regression. Generally, the fitting degree of the model is good, and the key explanatory variables basically pass the significance test with expected directions. The multicollinearity of the regression variables is examined by the variance inflation factor (VIF). The mean VIF is 5.63, which is less than the threshold value 10 [39]. The only variable close to the threshold is land scale and its square, due to the latter being derived directly from the former. Therefore, there is no evidence of multicollinearity in the analysis. What's more, heteroskedasticity robust standard errors are applied in the regressions.

Table 4. Regression results for the multivariate probit model.

\begin{tabular}{|c|c|c|c|c|c|}
\hline & Farm Manure & $\begin{array}{c}\text { Commercial } \\
\text { Organic Fertilizer }\end{array}$ & $\begin{array}{c}\text { Formula } \\
\text { Fertilization }\end{array}$ & $\begin{array}{l}\text { Green Manure } \\
\text { Plantation }\end{array}$ & Straw Returning \\
\hline Age & $-0.006(0.080)$ & $0.049(0.083)$ & $-0.066(0.072)$ & $-0.039(0.086)$ & $-0.118(0.088)$ \\
\hline Cadre & $-0.124(0.372)$ & $0.055(0.393)$ & $0.660 * *(0.321)$ & $-0.164(0.472)$ & $0.441(0.469)$ \\
\hline Risk & $-0.219 * *(0.108)$ & $-0.222 *(0.119)$ & $0.114(0.099)$ & $-0.038(0.128)$ & $0.108(0.122)$ \\
\hline Hsize & $-0.027(0.167)$ & $0.304 *(0.172)$ & $0.288 *(0.156)$ & $-0.119(0.209)$ & 0.007 (0.199) \\
\hline Lscale & $-0.266(0.340)$ & $-0.640^{* * *}(0.328)$ & $0.624 *(0.372)$ & $-0.646 *(0.391)$ & $0.383(0.377)$ \\
\hline Lscale $^{\wedge} 2$ & $0.017(0.033)$ & $0.057 *(0.032)$ & $-0.062 *(0.034)$ & $0.067 *(0.036)$ & $-0.037(0.037)$ \\
\hline Fragmentation & $-0.053(0.050)$ & $0.028(0.051)$ & $0.187^{* * *}(0.052)$ & $0.036(0.068)$ & $0.062(0.078)$ \\
\hline Road & $0.107 *(0.061)$ & $-0.006(0.065)$ & $-0.018(0.058)$ & $0.054(0.071)$ & $0.102(0.069)$ \\
\hline Rotation & $-0.084(0.177)$ & $0.051(0.210)$ & $-0.416^{* * *}(0.157)$ & $-0.234(0.182)$ & $0.141(0.147)$ \\
\hline Subsidy & $-0.122(0.150)$ & $0.401 * *(0.174)$ & $-0.251 *(0.131)$ & $-0.185(0.164)$ & $0.118(0.158)$ \\
\hline Region & $-0.009(0.188)$ & $0.445^{* *}(0.199)$ & $-0.406^{* *}(0.180)$ & $-0.852 * * *(0.247)$ & $2.672 * * *(0.258)$ \\
\hline Constant & $-0.419(1.413)$ & $-2.724 *(1.545)$ & $-2.029(1.407)$ & $-1.856(1.650)$ & $-4.205^{* * *}(1.564)$ \\
\hline
\end{tabular}

Note: Log likelihood $=-1163.84$, Wald $X^{2}(126)=479.62$, and $p$-value $=0.000$. The parenthesis is robust standard error. ${ }^{*}, * * * * *$ denote statistical significance at $10 \%, 5 \%$, and $1 \%$. 


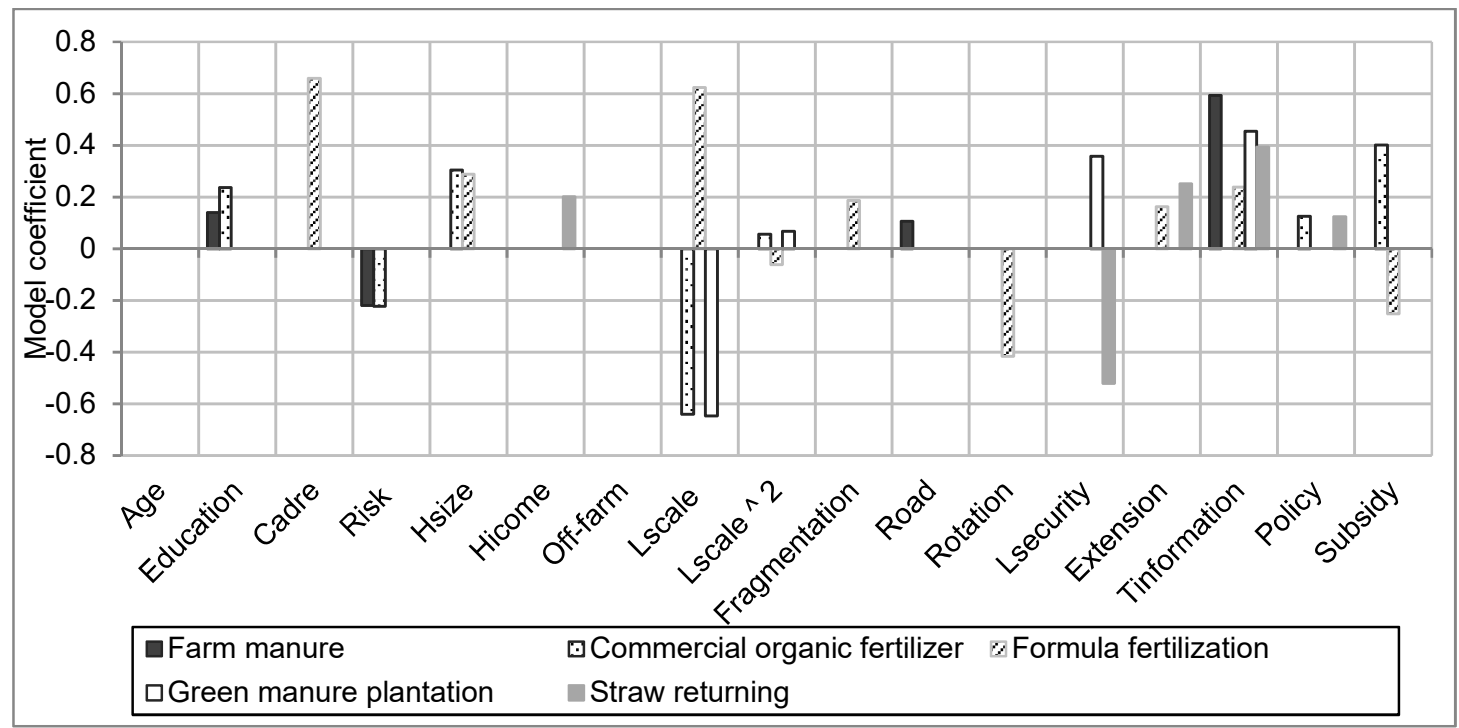

Figure 3. Determinants of LCTs' application for large-scale grain producers. The bars are independent variables with significant effect $(p<0.1)$, showing the impact direction (positive or negative) and magnitude (length of the bar).

\subsubsection{Farmer Characteristics}

Among the variables related to human capital, the formal education of the household head plays a positive role on the application of soil fertility improvement technology or environment-friendly agricultural technology [22,40]. As expected, the coefficients of education on all of the LCT models are positive, and the coefficients of farm manure application and commercial organic fertilizer use appear significant at $10 \%$ and $1 \%$, respectively, which implies that higher education can promote the application of LCTs for large-scale grain producers (see Figure 3 and Table 4). It is because farmers with higher education are more aware of environmental protection and more easily accept the advanced scientific ideas and technologies.

The village cadre variable is positively related to the adoption of formula fertilizer. A possible explanation is that the village cadres are the main participants involved in soil testing and formula design, which are the most important processes of formula fertilizer production. Therefore, the farmers with village cadre positions know more about this technology, resulting in a higher possibility of application. It is in accordance with the conclusion that the farmers' policy arena plays an important role in the adoption of innovations and technical extensions [41].

Available studies have indicated that farmers with risk preference are more likely to adopt new agricultural technology [42-44]. As shown in Table 4 and Figure 3, risk preference shows a significant negative correlation with the two traditional technologies. More concretely, keeping the other variables constant, a one-point growth in the risk preference score is associated with a decrease in the probability of adopting farm manure application and commercial organic fertilization by approximately 0.219 and 0.222 , respectively. However, risk attitude has no effect on the application of new technologies such as formula fertilization and straw returning technology.

\subsubsection{Farm Household Characteristics}

Household size represents the reserve of human resource. According to the literature, labor constraints may influence farmers' technology adoption $[45,46]$, especially constraints regarding the application of a labor-intensive technology [47]. As a result, the household size has a significant role in promoting the application of commercial organic fertilizer use and formula fertilization, suggesting that the more abundant the labor force, the more conducive the adoption of labor-intensive technology, which is in accordance with the conclusions of Thangata and Alavalapati [48]. Specifically, 
while the other variables are fixed, a one-person increase in family members is associated with a growth in the probability of adopting commercial organic fertilizer and formula fertilization by approximately 0.304 and 0.288 , respectively.

Previous studies have indicated that farm income affects the ability to adopt innovations due to farmers with higher farm incomes having access to more resources to purchase inputs and acquire information prerequisites in order to adopt a new technology [41]. As observed in Table 4 and Figure 3, the coefficient of this variable just shows a significantly positive impact on the straw returning technology application model. A possible explanation is that the farmers who adopt this technology need to spend extra RMB 20 80 per mu (USD 44 176 per ha) on hiring machinery to smash the straw before putting it into the field, and the farmers with higher income are more capable of adopting the higher cost technology. Meanwhile, the impacts of household income on the other four technologies are not statistically significant, indicating that the economy is not the main constraint on the application of these technologies by large-scale grain producers.

\subsubsection{Land Endowment and Infrastructure}

Farmers with large land scale will benefit from economies of scale when using more inputs as the returns will be larger, and this also occurs in the application of new agricultural technologies. That is, a large land scale would increase the probability of adopting new agricultural technologies [42,49-51]. However, the results reveal significantly non-monotonous effects of land scale on commercial organic fertilization, formula fertilization, and green manure plantation, which indicate that the expansion of land scale does not necessarily lead to the rise or decline of the technology application rate. On one hand, land scale has a significant inverted U-shaped relationship to the application of formula fertilization with an inflection point at $153 \mathrm{mu}(10.20 \mathrm{ha})$. One possible explanation is that at the beginning of land-scale expansion, the application rate of formula fertilization may rise due to the obvious economies of scale (cost reduction and profit increase). However, with the further expansion of land scale, high transaction costs regarding supervision and management lead to the gradual decrease of the application of labor-intensive technologies. This result is similar to the conclusion obtained by Liu et al. [52]. On the other hand, the land-scale variable appears to have a significant U-shaped relationship to both commercial organic fertilization and green manure plantation, with turning points at $207 \mathrm{mu}(13.80 \mathrm{ha})$ and $124 \mathrm{mu}(8.27 \mathrm{ha})$, respectively. This is in accordance with the results of Man et al. [53] and Guastella et al. [54], who indicated that the technology investment would not be worth it below the land threshold, especially on medium or long-term investments [53]. Therefore, large-scale grain producers may have the threshold of land scale when they select some medium or long-term investment such as organic manure and green manure plantation, and the possibility of adopting such kinds of technologies would be greatly improved upon only reaching a certain land scale.

Land fragmentation refers to farmers that have more pieces of land that are also small in size and scattered in different places. Land fragmentation has shown to pose a challenge in labor allocation [55] and management [42], which is detrimental to the adoption of some soil improvement technologies [56]. Unexpectedly, land fragmentation has positive impacts on the application of most LCTs, and is statistically significant at $1 \%$ in the formula fertilization model. After controlling for the other variables, a one-plot increase leads to the probability of formula fertilization application rising by about 0.187 . A possible explanation is that farmers are eager to compensate for the efficiency loss caused by land fragmentation through adopting LCTs, which can improve the soil fertility in the short term. Formula fertilizer is a kind of chemical fertilizer that can achieve this aim, while the other four technologies belong to long-term investments.

Available researchers have concluded that stable land property rights effectively stimulate farmers' land conservation investment, especially some long-term investments [57-59], because farmers are not willing to invest in land that possibly belongs to someone else next year [60,61]. As a result, there is a significant positive correlation between land tenure security and green manure plantation. It is said 
that farmers obtained the certificate of rented land's management right, meaning that stable land property rights are more favorable for applying medium or long-term agricultural technology, such as green manure plantation. This result is in accordance with the conclusion of previous studies [57,58,62]. However, unexpectedly, land tenure security and straw returning technology show a significant negative correlation. The possible explanation is that the straw returning technology is still imperfect at present in China. Many respondents observed that the machine cannot smash the straw completely, which hindered the operation of the land plough, as well as irrigation and fertilization in the later period. What's worse, soil microorganism breed from straw decay would snatch nutrients against crop seedling, resulting in crop malnutrition and even death. Liu et al. [52] also found similar conclusions.

Perfect infrastructure in the field results in lower transportation cost, and is conducive to applying those technologies that need massive transportation, such as organic fertilizer. Normally, the application amount of chemical fertilizer purity is around $0.36 \mathrm{t} / \mathrm{ha}$, while the amounts of commercial organic fertilizer and farm manure for rice are approximately $4 \sim 6 \mathrm{t} / \mathrm{ha}$ and $15 \sim 22.5 \mathrm{t} / \mathrm{ha}$, respectively. Therefore, road construction is expected to have a positive effect on the application of farm manure and commercial organic fertilizer. Unexpectedly, the result appears to have no relationship between road construction and the application of LCTs, except regarding the application of farm manure. A possible explanation may be that the massive application amount of farm manure is mainly transported by tracts, which are highly dependent on road infrastructure in the field, while the other LCTs rely on road construction less due to their comparable smaller use amount farm manure application.

\subsubsection{Extension Service and Technical Information}

The extension service is used to deliver a good experience when applying agricultural technology to farmers. It is investigated that the farmers who maintained frequent contact with extension workers were better able to adopt the extended technology [22]. Similarly, the role of the extension service in effecting land-enhancing technology adoption was noted by Baidu-Forson [63]. As expected, the extension service has had promoting effects on the application of all of the LCTs. The coefficients regarding the formula fertilization and straw returning technology models turned out to be positive and statistically significant at $5 \%$ and $1 \%$, respectively. This revealed that it is very important to build a wide-reaching and functional extension system. Therefore, the farmers can easily access a technical guidance service, which is helpful for improving their understanding of the technological strength of the applications, and then transferring it into action.

Agricultural information plays an important role in applying LCTs [22,64]. If the farmers have access to accurate agricultural technical information, they can adequately understand the technical benefits and thus improve the possibility of technology application. As expected, the coefficients of technical information on five LCTs are positive, four of which are statistically significant. This reveals that the farmers who acquire technical information on good agricultural practices from various sources can enhance their application of LCTs. It is worth mentioned that most of the technical information is collective from TVs, networks, and especially mobile phones. As noted by the studies of Mittal and Tripathi [65] and Baumuller [66], telecommunication is becoming an important mode of agricultural information delivery and sharing among farmers.

\subsubsection{Policy Knowledge and Subsidy}

Agricultural policy knowledge has a great impact on environment-friendly technology adoption [67]. It is hypothesized that the large-scale grain producers with higher knowledge of land conservation policies such as the zero growth of chemical fertilizer have a greater possibility of adopting LCTs. As a result, the policies knowledge variable appears to have a significantly positive relationship with the use and application of commercial organic manure and straw returning technology. Specifically, keeping the other variables constant, after a one-grade improvement of policy knowledge, the application probabilities of commercial organic manure use and straw returning technology would increase 0.126 and 0.124 , respectively. 
Receiving governmental grants or subsidies is another effective factor for the application of LCTs, which can supply initial capital and reduce the technology cost [42,61]. The government has adjusted agricultural subsidies aiming to support land conservation and large-scale grain production in China since 2015. However, the results are quite different from expectations. Except for commercial organic fertilizer, subsidies have either no impacts or negative effect on the LCTs. The possible explanation is mainly related to the complex types of subsidies, but the integrated disbursement mode of subsidies in China. Specifically, large-scale grain producers can receive many types of agricultural subsidies, including subsidies on land fertility protection, land scale management, straw returning, green manure plantation, and subsidies on environmental fertilization such as organic fertilizer and formula fertilizer (see Appendix A). However, all kinds of agricultural subsidies are dispensed together through a bank card named the "one-card-pass"; thus, the farmers are not clear about the exact type and amount of different subsidies. Therefore, it is difficult to observe the driving effect of relevant subsidy variables on the application of LCTs.

\section{Discussion and Conclusions}

This paper empirically analyzes the correlation effect and determinants of the application of LCTs using a multivariate probit model based on survey data collected in the middle and lower reaches of the Yangtze River in China. Our empirical results show that the overall application of LCTs is not very high, which was expected. The application rate of straw returning technology is the highest, reaching $72.75 \%$, while the application rates of farm manure application, commercial organic fertilizer use, and green manure plantation are all less than 15\%. More efforts are needed by the technology promotion system to realize food security and environmental sustainability. The estimated results indicate that there are significant complementary relationships among farm manure application, commercial organic fertilizer use, and green manure plantation, as well as between formula fertilization and straw returning technology. Regarding the determinant of LCTs' application, highly educated farmers and farmers with a large farm size and high incomes are more likely to apply LCTs. The land management scale appears to have an inverted U-shaped relationship to formula fertilization, with an inflection point at $153 \mathrm{mu}(10.20 \mathrm{ha})$, while showing an U-shaped relationship with commodity organic fertilizer use and green manure plantation, with the turning points at $207 \mathrm{mu}$ (13.80 ha) and $124 \mathrm{mu}$ (8.27 ha), respectively. The results also show that extension services from agricultural technicians, the agricultural technical information that is available, and policy knowledge variables have positive effects on LCTs application, while the subsidy policy does not appear to have the expected effect.

The following policy implications can be derived from this study. Firstly, to increase the application of LCTs, more extension services and technical information should be offered by local public extension agencies. However, the Chinese extension system has low efficiency due to inadequate capital investment and technicians. As noted by Li et al. [68], there were only 11 technicians to supply extension services for 20,000 farmers in one county in China. We suggest increasing the investment in extension infrastructure as well as building the capacity of the extension technicians on new and environment-friendly technologies, including dissemination strategies, in order to increase the application of LCTs. Another important implication for policymakers is to encourage bottom-up participation. Secondly, it calls for propaganda for environmental sustainability and relative policies to enhance farmers' cognition of land conservation and their policy knowledge. Moreover, we should broaden and diversify the channels for delivering technology information and environmental policy to large-scale grain producers, and let them play a demonstration role to the small-scale farmers. For technology extension tools, training and in-field guidance, television, radio, and cell phones are also important effective media for technology extension. Thirdly, we should make good use of the complementarity relationship among the LCTs, and bindingly propagate the complementary technologies during their extension. On the one hand, we can accurately select the training targets based on the complementary relationship to improve the application rate. On the other hand, compared with the individual technical extension, bundling promotion can improve the attraction of 
LCTs to large-scale grain producers. For example, formula fertilization can increase profits by around RMB 50 per mu (USD 110 per ha), while straw returning technology can raise profits by about RMB 30 per mu (USD 66 per ha). If the two technologies are adopted together, it can improve by RMB 4000 (USD 587) in total for a farmer with $50 \mathrm{mu}$ of land area (3.33 ha). Regarding the selection of training target farmers, education, farm size, and land scale are also strongly related to the adoption of LCTs, as indicated earlier. This suggests that the extension should be classified in accordance with the specific technical characteristics and farmers' characteristics in order to improve the possibility of adopting the LCTs. Last but not least, the existing subsidy policies have not achieved the expected effect on promoting the adoption of LCTs, because of the diversification and confusion of the subsidy system. Therefore, how to mobilize the relevant subsidy policies to play a joint effect and improve the extension efficiency is still a practical problem that is worthy of further study.

Author Contributions: Conceptualization, X.L. and S.F.; Formal Analysis, X.L., S.F. and H.L.; Funding Acquisition, X.L., S.F. and B.Z.; Data Curation, X.L. and S.F.; Methodology, X.L. and S.F.; Writing-Review \& Editing, X.L. and S.F.

Funding: This research is supported by National Natural Science Foundation of China, under Grant: 71503113; 71673144; 71503174; Jiangxi Province Social Science planning Foundation, under Grant: 18GL08; National Special Project on Science and Technology Statistics of China, under Grant: NSTS201713; 333 High Level Talents Training Project of Jiangsu Province; Six Talents Peak High Level Talent Project of Jiangsu Province, under Grant: 2016-NY-067; PhD project launched by Jiangxi Normal University; Tender Project of Jiangxi Economic Development Research Institute; Tender Project of Jiangxi Industrial Transformation and Upgrading Research Center.

Conflicts of Interest: The authors declare no conflict of interest.

\section{Appendix A}

See Table A1.

Table A1. Parts of agricultural subsidies to farmers in China.

\begin{tabular}{|c|c|c|c|}
\hline Type & Aim & Object & Standard \\
\hline $\begin{array}{l}\text { 1. Land fertility } \\
\text { protection }\end{array}$ & $\begin{array}{l}\text { Farmland should not be } \\
\text { abandoned, and soil fertility } \\
\text { should be improved. }\end{array}$ & $\begin{array}{l}\text { Farmers with the } \\
\text { right to contract for } \\
\text { management }\end{array}$ & $\begin{array}{l}\text { Single crop RMB } 105 \text { per mu } \\
\text { (USD } 232 \text { per ha); double crop } \\
\text { RMB } 175 \text { per mu (USD } 386 \text { per ha) }\end{array}$ \\
\hline $\begin{array}{l}\text { 2. Large-scale } \\
\text { management }\end{array}$ & $\begin{array}{l}\text { Encourage scale planting, } \\
\text { especially for grains (rice } \\
\text { and wheat) }\end{array}$ & $\begin{array}{l}\text { Farmers with } \\
\text { operated area over } \\
50 \mathrm{mu}(3.33 \mathrm{ha})\end{array}$ & $\begin{array}{l}\text { RMB } 60 \text { per mu (USD } 132 \text { per ha), } \\
\text { and upper limit at RMB 12,000 } \\
\text { (USD1765) for each farm }\end{array}$ \\
\hline $\begin{array}{l}\text { 3. Organic } \\
\text { fertilization }\end{array}$ & $\begin{array}{l}\text { Encourage using organic } \\
\text { manure to increase soil } \\
\text { fertility }\end{array}$ & $\begin{array}{l}\text { Farmers use organic } \\
\text { manure in pilot areas }\end{array}$ & RMB 200 per ton (USD29 per ton) \\
\hline $\begin{array}{l}\text { 4. Formula } \\
\text { fertilization }\end{array}$ & Formula fertilizer extension & $\begin{array}{l}\text { Farmers use formula } \\
\text { fertilizer in } \\
\text { pilot areas }\end{array}$ & RMB 300 per ton (USD44 per ton) \\
\hline $\begin{array}{l}\text { 5. Green manure } \\
\text { plantation }\end{array}$ & $\begin{array}{l}\text { Encourage planting green } \\
\text { manure to increase soil } \\
\text { fertility }\end{array}$ & $\begin{array}{l}\text { Farmers plant green } \\
\text { manure }\end{array}$ & Give green manure seeds for free \\
\hline $\begin{array}{l}\text { 6. Straw } \\
\text { returning }\end{array}$ & $\begin{array}{l}\text { Ban straw burning, and } \\
\text { return straw to land to } \\
\text { increase soil fertility and } \\
\text { prevent air pollution }\end{array}$ & $\begin{array}{l}\text { Farmers adopt straw } \\
\text { returning technology }\end{array}$ & $\begin{array}{l}\text { Range RMB } 20-50 \text { per mu } \\
\text { (USD44 110 per ha) }\end{array}$ \\
\hline
\end{tabular}

Note: All the subsidies come from national finance, and the subsidy standard may slightly differ among various regions according to land scale, numbers of farmers, and local budget. 


\section{References}

1. National Bureau of Statistics of China. China Statistical Yearbook in 2017. Available online: http://www.stats. gov.cn/tjsj/ndsj/2017/indexeh.htm (accessed on 8 October 2017).

2. Zhang, L.X.; Huang, J.K.; Fang, Q.B. Economic assess and analyze of farmers' fertilization. In Policy for Reducing Non- Point Pollution from Crop Production in China; Zhu, Z.L., David, N., Sun, B., Eds.; China Environmental Science Press: Beijing, China, 2006; pp. 81-100. (In Chinese and English)

3. Mo, F.L.; Liao, B.; Lin, W. Present status and counter measures of agricultural non-point source pollution. Environ. Sci. Surv. 2009, 28, 51-54. (In Chinese)

4. Jin, L.S.; Wang, J.N. Impact Analysis of Chinese Agricultural Development on Environment. Environmental Policy (Vol.1); China Environmental Science Press: Beijing, China, 2004; pp. 74-105. (In Chinese)

5. Guo, J.H.; Liu, X.J.; Zhang, Y. Significant acidification in major Chinese croplands. Nature 2010, 327, $1008-1010$. [CrossRef] [PubMed]

6. Cai, R. Agri-chemicals inputs and its impact on environment. China Pop. Res. Environ. 2010, 20, 107-110. (In Chinese)

7. Gao, Y.X.; Gao, X.B.; Liang, X.H. Fertilization technology and agricultural sustainable development. Chin. Rural Econ. 1999, 10, 28-33. (In Chinese)

8. Yan, X.; Jin, J.Y.; He, P. Recent advances in technology of increasing fertilizer use efficiency. Sci. Agric. Sin. 2008, 41, 450-459. (In Chinese)

9. Huang, J.K.; Huang, Z.; Jia, X. Long-term reduction of nitrogen fertilizer use through knowledge training in rice production in China. Agric. Syst. 2015, 135, 105-111. [CrossRef]

10. Zhang, J.J.; Fu, M.C.; Zhang, Z.Y.; Tao, J.; Fu, W. A trade-off approach of optimal land allocation between socio-economic development and ecological stability. Ecol. Model. 2014, 272, 175-187. [CrossRef]

11. Deng, X.Z.; Gibson, J.; Wang, P. Management of trade-offs between cultivated land conversions and land productivity in Shandong Province. J. Clean. Prod. 2017, 142, 767-774. [CrossRef]

12. Liu, X.W.; Zhao, C.L.; Song, W. Review of the evolution of cultivated land protection policies in the period following China's reform and liberalization. Land Use Policy 2017, 67, 660-669. [CrossRef]

13. Jones, S. A Framework for understanding on-farm environmental degradation and constraints to the adoption of soil conservation measures: Case studies from highland Tanzania and Thailand. World Dev. 2002, 30, 1607-1620. [CrossRef]

14. Awoyinka, Y.; Awoyemi, T.; Adesope, A. Determinants of farmers' perception of land degradation and adoption of soil conservation technologies among rice farmers in Osun-State, Nigeria. J. Environ. Ext. 2006, 5, 45-50. [CrossRef]

15. Hou, D.; Liu, K. Farmers' Perception and Adaptation Behavior Concerning Land Degradation: A Theoretical Framework and a Case Study in Northwest China. In Proceedings of the EGU General Assembly Conference, Vienna, Austria, 23-28 April 2017.

16. Mbaga-Semgalawe, Z.; Folmer, H. Household adoption behaviour of improved soil conservation: The case of the North Pare and West Usambara Mountains of Tanzania. Land Use Policy 2000, 17, 321-336. [CrossRef]

17. Nunez, J.; Mccann, L. Crop Farmers' Willingness to Use Manure. In Proceedings of the American Agricultural Economics Association Annual Meeting, Denver, CO, USA, 1-4 August 2004.

18. Wiredu, A.N.; Martey, E.; Fosu, M. Describing adoption of integrated soil fertility management practices in northern Ghana. Presented at the Conference on International Research on Food Security, Natural Resource Management and Rural Development, Prague, Czech Republic, 17-19 September 2014.

19. Akinola, A.A.; Alene, A.D. Determinants of adoption and intensity of use of balance nutrient management systems technologies in the northern Guinea savannah of Nigeria. Q. J. Int. Agric. 2010, 49, 25-45.

20. Asfaw, S. Agricultural technology adoption, seed access constraints and commercialization in Ethiopia. J. Dev. Agric. Econ. 2011, 9, 436-447.

21. Kassie, M. Understanding the adoption of a portfolio of sustainable intensification practices in eastern and southern Africa. Land Use Policy 2015, 42, 400-441. [CrossRef]

22. Mponela, P.; Tamene, L.; Ndengu, G. Determinants of integrated soil fertility management technologies adoption by smallholder farmers in the Chinyanja Triangle of Southern Africa. Land Use Policy 2016, 59, 38-48. [CrossRef] 
23. David-Benz, H.; Penot, E.; Bignebat, C. Using Sustainable Rural Livelihoods framework to analyze the determinants of adoption and disadoption of conservation agriculture in Western Madagascar. In Proceedings of the JRSS, Lyon, France, 14-15 December 2017.

24. Ministry of Agriculture and Rural Affairs. The Proportion of the Transfer of Contracted Cultivated Land in the Country has Exceeded 1/3. Available online: http://news.xinhuanet.com/politics/2016-11/17/c_1119933443. htm (accessed on 17 November 2016).

25. Wong, M.H. Heavy metal contamination of soils and crops from auto traffic, sewage sludge, pig manure and chemical fertilizer. Agric. Ecosyst. Environ. 1985, 13, 139-149. [CrossRef]

26. Atafar, Z.; Mesdaghinia, A.; Nouri, J. Effect of fertilizer application on soil heavy metal concentration. Environ. Monit. Assess. 2010, 160, 83-89. [CrossRef]

27. He, L.Y.; Huang, J.K. Stability of land use rights and fertilizer use: An empirical study of Guangdong Province. China Rural Obser. 2001, 5, 42-48. (In Chinese)

28. Sun, D. Types, characteristics and application methods of commercial organic fertilizers. Agric. Knowl. 2004, 4, 24. (In Chinese)

29. Dobermann, A.; Witt, C.; Dawe, D.; Abdulrachman, S.; Gines, H.C.; Nagarajan, R. Site-specific nutrient management for intensive rice cropping systems in Asia. Field Crop. Res. 2002, 74, 37-66. [CrossRef]

30. Chen, M.; Ma, T.T.; Ding, Y.P. Effects of formula fertilizer application on nutrient uptake and grain yield of rice. J. Plant Nutr. Fertil. 2014, 20, 237-246. (In Chinese)

31. Senaratne, R.; Ratnasinghe, D.S. Nitrogen fixation and beneficial effects of some grain legumes and green-manure crops on rice. Biol. Fertili. Soils 1995, 19, 49-54. [CrossRef]

32. Praharaj, C.S.; Sankaranarayanan, K.; Khader, S.E.S.A. Sustaining cotton productivity and soil fertility through in situ management of green manure and crop residues in semi-arid irrigated condition of Tamil Nadu. Indian J. Agron. 2009, 54, 415-422.

33. Liu, S.; Nie, X.; Zhang, H. Effects of tillage and straw returning on soil fertility and grain yield in a wheat-rice double cropping system. Trans. Chin. Soc. Agric. Eng. 2006, 22, 48-51. (In Chinese)

34. Nie, J.; Zhou, J.M.; Wang, H.Y. Effect of long-term rice straw return on soil glomalin, carbon and nitrogen. Pedosphere 2007, 17, 295-302. [CrossRef]

35. Greene, W.H. Econometric Analysis; Prentice Hall: Upper Saddle River, NJ, USA, 2008.

36. Smith, L.E.D.; Siciliano, G. A comprehensive review of constraints to improved management of fertilizers in China and mitigation of diffuse water pollution from agriculture. Agric. Ecosyst. Environ. 2015, 11, 15-25. [CrossRef]

37. Zhou, Y.; Yang, H.; Mosler, H.J.; Abbaspour, K.C. Factors affecting farmers decisions on fertilizer use: A case study for the Chaobai Watershed in Northern China. Cons. J. Sustain Dev. 2010, 4, 80-102.

38. Pan, D.; Kong, F.B.; Zhang, N. Knowledge training and the change of fertilizer use intensity: Evidence from wheat farmers in China. J. Environ. Manag. 2017, 197, 130-139. [CrossRef]

39. Chen, X.; Ender, P.; Mitchell, M.; Wells, C. Stata Web Books: Regression with Stata. 2003. Available online: https://stats.idre.ucla.edu/stata/webbooks/reg/ (accessed on 15 January 2019).

40. Burton, R.J. The influence of farmer demographic characteristics on environment behavior: A review. J. Environ. Manag. 2014, 135, 19-26. [CrossRef]

41. Robinson, J.R.; Napier, T.L. Adoption of nutrient management techniques to reduce hypoxia in the Gulf of Mexico. Agric. Syst. 2002, 72, 197-213. [CrossRef]

42. Shiferaw, B.; Holden, S.T. Resource degradation and adoption of land conservation technologies in the Ethiopian Highlands: A case study in Andit Tid, North Shewa. Agric. Econ. 1998, 18, 233-247. [CrossRef]

43. Schutjer, W.A.; Van der Veen, M. Economic Constraints on Agricultural Technology Adoption in Development Countries; Occasional Paper No. 5; U.S. Agency for International Development, USAID: Washington, DC, USA, 1977.

44. Feder, G. Farm size, risk aversion and the adoption of new technology under uncertainty. Oxf. Econ. Pap. 1980, 32, 263-283. [CrossRef]

45. Feder, G.; Just, R.E.; Zilberman, D. Adoption of agricultural innovations in developing countries: A survey. Econ. Dev. Cult. Chang. 1985, 33, 255-297. [CrossRef]

46. Enyong, L.A.; Debrah, S.K.; Bationo, A. Farmers' perceptions and attitudes towards introduced soil-fertility enhancing technologies in western Africa. Nutr. Cycl. Agroecosyst. 1999, 53, 177-187. [CrossRef] 
47. Dvorak, A.K. Adoption Potential of Alley Cropping; Final Project Report; Resource and Crop Management Research Monograph, No. 23; International Institute of Tropical Agriculture (IITA): Ibadan, Nigeria, 1996.

48. Thangata, P.H.; Alavalapati, J.R.R. Agroforestry adoption in southern Malawi: The case of mixed intercropping of Gliricidia sepium and maize. Agric. Syst. 2003, 78, 57-71. [CrossRef]

49. Khanna, M. Sequential adoption of site -specific technologies and its implication for nitrogen productivity: A double selectivity model. Am. J. Agric Econ. 2001, 83, 35-51. [CrossRef]

50. Asafu-Adjaye, J. Factors Affecting the Adoption of Soil Conservation Measures: A Case Study of Fijian Cane farmers. J. Agric. Res. Econ. 2008, 33, 99-117.

51. Harris, D.; Orr, A. Is rainfed agriculture really a pathway from poverty? Agric. Syst. 2014, 123, 84-96. [CrossRef]

52. Liu, L.; Zhang, J.; Zhang, C.S. Does the expansion of business scale help farmers to adopt environmentally friendly production behavior? Taking straw returning as an example. J. Agrotech. Econ. 2017, 17-26. (In Chinese)

53. Man, M.J.; Zhou, M.L.; Li, T.S. Analysis of differences in technical behavior of farmers with different attributes: Based on the survey of Shaanxi, Gansu and Ningxia. China Rural Econ. 2010, 2, 68-78. (In Chinese)

54. Guastella, G. Investment Behaviour of EU Arable Crop Farms in Selected EU Countries and the Impact of Policy Reforms; Factor Markets Working Paper No. 42; Centre for European Policy Studies (CEPS): Brussels, Belgium, 2013.

55. Adimassu, Z.; Langan, S.; Johnston, R. Understanding determinants of farmers' investments in sustainable land management practices in Ethiopia: Review and synthesis. Environ. Dev. Sustain. 2016, 18, 1005-1023. [CrossRef]

56. Chinangwa, L.L.R. Adoption of Soil Fertility Improvement Technologies among Smallholder Farmers in Southern Malawi. Available online: http://www.umb.no/statisk/noragric/publications/master/2006_linda_ chinangwa.pdf (accessed on 27 June 2014).

57. Jacoby, H.G.; Li, G.; Rozelle, S. Hazards of expropriation: Tenure insecurity and investment in rural China. Am. Econ. Rev. 2002, 92, 1420-1447. [CrossRef]

58. Yao, Y.; Carter, M.R. Land Tenure, Factor Proportions and Land Productivity: Theory and Evidence from China; Working Paper; Department of Agricultural and Applied Economics, University of Wisconsin-Madison: Madison, WI, USA, 1996.

59. Akinola, A.A.; Ikudayisi, J.O.; Ayedun, B. Property Rights and Adoption of Land Management Practices in Ekiti State, Nigeria. Int. J. Agric. For. 2014, 3, 217-223.

60. Demeke, A.B. Factors Influencing the Adoption of Introduced Soil Conservation Practices in Northwestern Ethiopia; Discussion Paper; Institute of Rural Development, University of Goettingen: Goettingen, Germany, 2003.

61. Haghjou, M.; Hayati, B.; Choleki, D.M. Identification of factors affecting adoption of soil conservation practices by some rainfed farmers in Iran. J. Agric. Sci. Tech. 2014, 16, 957-967.

62. Li, G.; Rozelle, S.; Brandt, L. Tenure, land rights, and farmer investment incentives in China. Agric. Econ. 1998, 19, 63-71. [CrossRef]

63. Baidu-Forson, J. Factors influencing adoption of land-enhancing technology in the Sahel: Lessons from a case study in Niger. Agric. Econ. 1999, 20, 231-239. [CrossRef]

64. Nowak, P.J. The adoption of agricultural conservation technologies: Economic and diffusion explanations. Rural Sociol. 1987, 52, 208-220.

65. Mittal, S.; Tripathi, G. Role of mobile phone technology in improving small farm productivity. Agric. Econ. Res. Rev. 2009, 22, 451-459.

66. Baumuller, H. Facilitating Agricultural Technology Adoption among the Poor: The Role of Service Delivery through Mobile Phones; Working Paper Series 93; Center for Development Research, University of Bonn: Bonn, Germany, 2012. 
67. Pan, D. The Design of Policy Instruments towards Sustainable Livestock Production in China: An Application of the Choice Experiment Method. Sustainability 2016, 8, 611. [CrossRef]

68. Li, Y.; Zhang, W.; Ma, L.; Huang, G.; Oenema, O.; Zhang, F.; Dou, Z. An analysis of China's fertilizer policies: Impacts on the industry, food security, and the environment. J. Environ. Qual. 2013, 42, 972-981. [CrossRef] [PubMed] 